\title{
4. Hagiographic Romance
}

As the preeminent Old Testament type of the suffering and resurrected Christ, Job foreshadows all the saints, male and female, whose steadfast virtue, subjected to satanic testing through serial misfortunes, merits the reward of restored happiness. Allegorized as an Iliadic spiritual battle and an Odyssean spiritual journey back to the Fatherland, the history of patient Job, sorely tried and ultimately victorious, stands parallel to the heroic narratives of both pagan and Christian saints and mediates between them. It recalls, on the one hand, the afflictive adventures of Aeneas, Odysseus, and the virtuous young lovers in Hellenistic romance and inspires, on the other, imitation in the legenda of popular Joban saints like Eustace, Griselda, and Constance. ${ }^{1}$ These legenda, as we shall see, mediate in turn between the books of Job and Boethius, using

1. Lawrence L. Besserman rightly observes that "an awareness of the various manifestations of Job in medieval culture puts us in a better position to appreciate works like Chaucer's "Man of Law's Tale," Gower's Tale of Constance, and romances like Sir Isumbras, Robert of Cisyle, Amis and Amiloun, as well as other stories of the Eustace-Constance-Griselda type - that is, stories of suffering, loss, trial, and reward at the hands of a merciful God" (The Legend of Job in the Middle Ages [Cambridge: Harvard University Press, 1979], p. 113). As Derek Pearsall notes, many Middle English chivalric romances-among them, Octavian, Athelston, Sir Ysumbras, Sir Eglamour, Torrent of Portygale, and Sir Triamour-exhibit a basic plot of trial, constancy, and reward. See "The Development of Middle English Romance," Medieval Studies 27 (1965): 92. Sometimes the exemplification of virtue in such romances verges on hagiography. See Ojars Kratins, "The Middle English Amis and Amiloun: Chivalric Romance or Secular Hagiography?" PMLA 81 (1 966): 347-54. 
Boethius' Consolation intertextually to qualify the world of (mis)fortune and human pain; Job to typify the realm of moral constancy, providential design, and happy endings.

Converting the story of Job into a romantic saint's legend necessarily required (1) a focus on the so-called frame narrative of initial prosperity, loss, testing, and miraculous restoration; (2) a reduction of the central dialogues to one more test in an expandable series of superhuman trials; and (3) a static characterization of the hero as one who remains unchanged in the midst of a mutable universe. We have already observed how the episodes of classical epic, interpreted as moral exempla, found a romantic retelling in the popular works of Chariton, Xenophon of Ephesus, Heliodorus, Achilles Tatius, and Apuleius. Similarly, the impulse to moralize the Book of Job, to make its hero exemplary for a wide Christian audience, led to its retelling as hagiographic romance. ${ }^{2}$

The ability of these romantic legenda to evoke multiple narrative parallels-from the Bible, from popular fiction and folklore, as well as from philosophical works like the Consolation of Boethius-enhanced their exemplary value and imaginative appeal for their medieval auditors, who were invited to draw analogies between the $l e$ genda and their own lives, extending the moral of each story from one application to another. The more parallels one could see, the better. Thomas Heffernan rightly observes that the medieval "hagiographer was especially concerned to use deliberate verbal reminiscences of earlier texts (principally biblical) in constructing his narrative." 3 Such echoes simultaneously define the saint as a follower and imitator of Christ and canonize him or her as imitable by others. Whereas saints' lives with a firm historical grounding tend to emphasize biblical parallels, the tales of hagiographic romance selfconsciously allude to both scriptural and secular stories, evoking

2. For pertinent discussions of hagiographic romance, see Diana T. Childress, “Between Romance and Legend: 'Secular Hagiography' in Middle English Literature," Philological Quarterly 57 (1978): 31 1-22; Andrea Hopkins, The Sinful Knights: A Study of Middle English Penitential Romance (Oxford: Clarendon Press, 1990), especially pp. 1-20. Following A. V. C. Schmidt and Nicolas Jacobs, Hopkins emphasizes the comic and didactic nature of romance in general, and religious romance in particular.

3. Thomas J. Heffernan, "An Analysis of the Narrative Motifs in the Legend of St. Eustace," Medievalia et Humanistica, n.s. 6 (1975): 68-69. 
both simultaneously, if not equally. As Tomas Hägg has phrased it, "The hagiographic novel is the life of a saint in which the fictitious element has got the upper hand."4

According to Hägg, "the novelistic form" in late antiquity "was the means of attracting pagan readers." ${ }^{5}$ Beginning in the second century with the emergence of the apocryphal Acts of the Apostles, "the same readership which provided a market for the Hellenistic novel was . . . devouring stories about apostles, martyrs, and saints." 6 Not only were the Ethiopica and Leucippe and Clitophon allegorized and attributed to Christian authorship and thus canonized $;^{7}$ original compositions-among them, the widely circulated Paul and Thecla (second century) and the popular Petrine Recognitiones of PseudoClement (fourth century) — transposed the episodes of pre-Christian romances into new, explicitly Christian, apologetic contexts. ${ }^{8}$ Finally, in the late fifth or early sixth century, possibly in the Vivarium of Cassiodorus, the Historia Apollonii Regis Tyri, based on a now lost pagan Greek romance, ${ }^{9}$ appeared in a thoroughly Christian recension. ${ }^{10}$

These late antique Christian romances prepared the way for the medieval saints' lives of Joban figures like Eustace, Griselda, and

4. Tomas Hägg, The Novel in Antiquity (Berkeley: University of California Press, 1983), p. 164 .

5. Ibid.

6. Ibid., p. 161 .

7. See Hägg, Novel in Antiquity, p. 59; Heinrich Dörrie, "Die griechischen Romane und das Christentum," Philologus 93 (n.s. 47) (1 938): 273-76.

8. For a treatment of Paul and Thecla, see Hägg, Novel in Antiquity, pp. 154-62; Gordon Hall Gerould, Saints' Legends (Boston and New York: Houghton-Mifflin, 1916), p. 33. For a discussion of the Recognitiones, see Ben Edwin Perry, The Ancient Romances: A Literary-Historical Account of Their Origins ((Berkeley: University of California Press, 1967), pp. 285-93; Hägg, pp. 162-64. According to Heffernan, there are over one hundred extant manuscripts of the Recognitiones ("Narrative Motifs," n. 45 , p. 9).

9. Perry has suggested that the Apollonius was inspired by either "an earlier form of the Ps.-Clementine story, or by the same source on which the latter was built" (The Ancient Romances, p. 295). See also p. 286.

1 o. Commenting on that recension, G. A. A. Kortekaas notes: "The Christian linguistic elements, varying from the use of words with Christian overtones to borrowings from the Bible and phraseology incidentally concurring with Italian (perhaps even Roman) hagiography form an integrated component of its language" (Historia Apollonii Regis Tyri, ed. G. A. A. Kortekaas [Groningen: Bouma's Boekhuis, 1984], p. 106). 
Constance. The conversion of pagan romance into hagiographic romance depended on the recognition of a parallel story or stories in Scripture to which the pagan narratives could relate as foreshadowing and the legenda as imitation. The Book of Job provided such a mediative biblical parallel, not only in the general outline of its plot, but also in its special character as a book of Gentile authorship providentially included in the Judeo-Christian canon.

Although the date and authorship of the Book of Job were debated by early exegetes, Gregory the Great and Isidore of Seville, following Saints Ambrose and Augustine, advanced the view that the Book was written by Job himself during the age of the patriarchs, before the time of Moses. After summarizing the views of others, Gregory concludes: "We nonetheless consider it more likely that the same holy Job who endured the battles of spiritual warfare also narrated the events of his own accomplished victory" (Preface I.3, p. 9: "Arbitrari tamen uerius possumus, quod isdem beatus Iob, qui certamina spiritalis pugnae sustinuit, etiam consummatae suae uictoriae gesta narrauit"). ${ }^{11}$

Job, moreover, was not a Jew but a Gentile. In the Preface to the Moralia, Gregory explains that Divine Providence included the life of a righteous Gentile among the lives of Hebrews (Preface II.5, p. 11: "inter Hebraeorum uitas . . . uita iusti gentilis adducitur") for three reasons: first of all, because Christ came to save Jews and Gentiles alike; secondly, in order that the virtue of a Gentile not under the Law ("homo gentilis, homo sine lege") might confound the narrow-mindedness ("prauitas") of those under the Law; thirdly, that the example of a noble pagan might counter the impudence of Christians: "Vnde ad confutandam impudentiam nostram, gentilis homo ad exemplum deducitur" (Preface II.4, p. 10). Similarly, Isidore praises Job as a Gentile famous for his faith, great in his humility, outstanding in hospitality, gentle in correction, generous in almsgiving: "homo gentilis, fide clarus, humilitate summus, hospitalitate praecipuus, in disciplina mansuetus, in eleemosynis largus." 12

This view of Job as a noble preredeemed pagan linked him in the

1 1. I quote from Gregory the Great, Moralia in Job, ed. M. Adriaen, CCSL 134 (Turnhout: Brepols, 1979). The translation is mine. Subsequent citations are parenthetical. See also Isidore of Seville, Etymologiae VI.ii.13-14, PL 82, c231.

1 2. Isidore of Seville, De ortu et obitu Patrum XXIV.37, PL 83, c1 36. 
medieval imagination to exempla of other unbaptized men of good will, such as Cornelius, Trajan, and the emperor Constantine, whose virtue merited them faith and salvation. Job's authorship of an inspired book, moreover, tended to affirm the typological value of pagan works and sanction their conversion into Christian literary forms for the sake of converting their readers. It is not surprising, therefore, that the saints' legends generally recognized for their indebtedness to Greek romance are also marked by their explicit or implicit allusions to the Book of Job.

Popular throughout the Middle Ages, the Life of Saint Eustace provides the clearest example of this synthesis of scriptural and secular materials. ${ }^{13}$ Scholars have commonly recognized resemblances in plot between the Life of Eustace, on the one hand, and the PseudoClementine Recognitiones and the story of Apollonius, Prince of Tyre, on the other. Gordon Hall Gerould, for instance, notes in the Eustacian vitae "a marked likeness in manner and material to the late Greek romances." 14 In his edition of the Anglo-Saxon recension of the Passio Sancti Eustacii Martyris (tenth century), Walter W. Skeat observes that the legend, unlike the others included in Elfric's saints' lives, is actually "a secular and romantic story" that is "turned into a 'saint's life' by the addition of the hero's martyrdom." 15 Skeat goes on to note that the story of the knight Placidas/Eustace actually appears in the English version of the Gesta Romanorum without the sequel of martyrdom, ending "happily, as it was clearly meant to do," given its strong orientation "on the story of Job." Following Skeat's lead,

13. After the first extant mention of Eustace by John of Damascus (A.D. 726), the Eustace legend became very popular in the West. According to Heffernan, "every century from the ninth to the fourteenth produced a Latin recension of the Legend" and versions abound "in virtually all European vernaculars" ("Narrative Motifs," pp. 65-66). For a discussion of the close relationship between Sir Isumbras and the Life of Eustace see Hopkins, Sinful Knights, pp. 1 19-43. During the Renaissance the story of Eustace was dramatized in (Nicholas Udall's?) Play of Placidas, Alias St. Eustace (1534), John Partridge's The worthie Hystorie of the most Noble and valiaunt Knight Placidas, otherwise called Eustas, who was martyred for the Profession of Jesus Christ (1566), and Henry Chettle's Sir Placidas (1599). See Gerould, Saints' Legends, pp. 3oo, 308, 316-17.

14. Gerould, Saints' Legends, p. 49. See also Heffernan, “Narrative Motifs," p. 72.

15. Walter W. Skeat, ed., Alfric's Lives of Saints, vol. 2 (London: Kegan Paul, Trench, Trübner and Co., 1 90o), p. 452. Scholars now question the attribution of the legend to Elfric. 
Heffernan has extensively explored the influence of the Vulgate in the narrative structure of the Eustace legend and termed the Book of Job "the single most important biblical antecedent." 16

In the Anglo-Saxon recension of the tale, Placidas is a military tribune (p. 190: "sum cempena ealdor-man") like Job, whom the church fathers had allegorized as God's warrior. ${ }^{17}$ The story begins with a listing of the good works of Placidas and his wife, even as the Bible enumerates Job's virtues. Like the Gentile Job, Placidas, still a heathen, draws the attention of the merciful and benevolent God ("se mild-heorta and se welwillenda god") who wills the salvation of all and finds acceptable the person "who worketh righteousness" (p. 193), no matter what his race or origin: "bæt on ælcre peode pe riht-wisnysse wyrcठ" (p. 192). One day while Placidas is hunting, Christ appears to him in the form of a miraculous stag who speaks to him, echoing the words of Christ to Paul on the road to Damascus. As a result, Placidas and his wife and two sons are baptized, and he is christened "Eustace."

The language of the narrative then plays with the famous nakedness of Job. Before his baptism, Placidas clothed the naked: "nacode he scrydde" (p. 19o). Through baptism, as Christ tells Eustace, he has divested himself (p. 196: "ठu unscryddest") of the corruptible man and vested himself ("gescryddest") with the incorruptible. As a result he has angered the devil, who will strip him of worldly wealth and thus allow him through suffering to gain spiritual riches in the service of the King of Heaven. Appearing to Eustace in the stag, Christ prophesies that he will be tried, even as His beloved servant Job (p. 198: "swa min leofa đeow iob") was tried, and eventually vanquish the devil through patience, if he avoids cursing and murmuring in his thoughts: "warna huru pæt nan wyrgung and ceorung astige on pinum gepohte" (p. 198).

The series of Joban trials begins. A pestilence kills Eustace's servants and livestock. When Eustace and his family temporarily flee the property, thieves take all their goods. While in flight to Egypt, a lustful captain demands Eustace's beautiful wife as ship-toll and, separated from her, Eustace loses his two sons in rapid succession,

16. Heffernan, "Narrative Motifs," p. 72. cally.

17. I quote from Skeat's edition, cited above, giving page references parentheti- 
one carried off by a lion, another by a wolf. Infused virtue strengthens Eustace in patience to keep him from suicide, but he begs God for an end to his trials, humbly observing that although Christ prophesied that he would be tested like Job (p. 202: "pæt ic sceolde gecostnod beon eall-swa iob"), he has actually suffered in some things even more than Job: "mare ic polige ponne he."

After fifteen years alone in a foreign land, Eustace hears a heavenly voice promising him restored happiness on earth and an even greater reward in Heaven. An invasion prompts the Roman emperor Trajan to send men in search of his excellent tribune, Placidas. Through a series of remarkable events, they find Eustace, whom they identify through a tell-tale scar; Eustace's two sons, who have been raised separately as foundlings by shepherds and husbandmen, recognize each other as brothers and find their mother, whose chastity and beauty have been miraculously preserved. She, in turn, is reunited with Eustace. This blissful reunion after long separation, like the reunions in Greek romance, prompts feasting and thanksgiving to God-a jubilant ending cut short in the saint's legend by the martyrdom of the whole family as Christians.

The Life of St. Eustace almost effortlessly fuses the plot materials of Greek romance with the biblical story of Job, subordinating the fiction of the former to the truth of the latter. In a similar fashion, but with considerably more difficulty, the equally popular exemplary tale of Patient Griselda ${ }^{18}$ joins a Beauty-and-the-Beast folktale with affinities to the Apuleian romance of Psyche and Cupid ${ }^{19}$ to the providential themes of Job and Boethius. ${ }^{20}$ In the tale of Griselda, the Book of Job does not simply mediate between folkloric romance and Christian saint's life; rather, a new textual triad forms at a higher level, wherein the saint's life mediates between scripture and philosophy, Job and Boethius. ${ }^{21}$

18. For an account of the various versions of the story, see Käte Laserstein, Der Griseldistoff in der Weltliteratur (Weimar: A. Duncker, 1926).

19. See Dudley David Griffith, The Origin of the Griselda Story (Seattle: University of Washington Press, 1931 ); Wirt Armistead Cate, "The Problem of the Origin of the Griselda Story," SP 29 (1932): 389-405.

20. For insight into the critical controversies surrounding the Griselda stories of Boccaccio, Petrarch, and Chaucer, see Mary J. Carruthers, "The Lady, the Swineherd, and Chaucer's Clerk," Chaucer Review 17.3 (1983): $221-34$.

21. Charlotte C. Morse ("The Exemplary Griselda," $S A C 7$ [1985]) notes that Chaucer's "Clerk's Tale" seems "rarely to have been copied apart from The Canter- 
Job

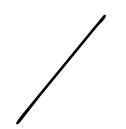

pagan romance

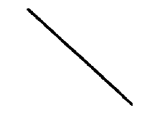

Christian romance

Hagiographic Romance

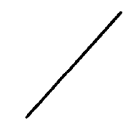

Job

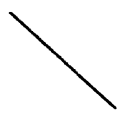

Boethius

In the process, as we shall see, the conflict that is elided in the Eustace legend by silencing the saint's complaint (and thus letting the Joban frame narrative eclipse the central, disturbing Dialogue of Comfort) reemerges in a dialogic concordance of Boethian and biblical texts.

\section{Griselda, Job, and Boethius}

The medieval tendency to derive the same moral lesson, the same meaning, from the Book of Job and Boethius' Consolation of Philosophy established a powerful parallel between the two texts that served to relate them as translationes, one of the other. Alluding to both Job and Boethius, the Griselda story tests the limits of that translatio by bringing the two texts into conjunction and conflict. As Griselda's husband and tormenter, Walter resembles at once the mysterious but benevolent God of Boethius and the Satan of Job. Similarly, Griselda figures simultaneously as Lady Philosophy and Job in her patient endurance of a series of terrible domestic trials. Assimilated to Lady Philosophy, Griselda does not apostrophize her fate as did the heroines of Greek and Roman romance whose calamitous stories parallel hers. As a female translatio of silent Job, moreover, Griselda undermines the Gregorian distinction between the blasphemous and the pious Job, which uses the dialogue between Job and his despairing wife to label weeping, suffering, and complaint as feminine; fortitude and reasoned composure as masculine. ${ }^{22}$ Thus the protagonists of the Griselda story, positioned between two closely related but subtly opposed Boethian and biblical interpretive grids, each have two faces,

bury Tales. It appears once with saints' lives and three times with romances, illustrating the tendency, particularly in the English tradition, to group saints' lives and romances" (n. 33, p. 66).

22. I address the issue of translatio and gender in a forthcoming essay, "Translating Job as Female," cited in n. 34 below. 
divine and diabolic, masculine and feminine, the potential schizophrenia of which Petrarch masks and Chaucer exposes.

In 1373 Petrarch wrote a Latin version of the Griselda story that Boccaccio had used to conclude his Decameron (1353). Petrarch's Griselda (Epistolae seniles 17.3) reflects his commitment to what Charlotte C. Morse has termed "a heavily Stoic, practical moral philosophy." ${ }^{23}$ As Morse observes, "Petrarch accommodates the story to classical rhetoric," keeping "overt Christian references" to a minimum. ${ }^{24}$ Petrarch's only allusion to Job comes in his closing moralization of the tale, and there it is indirect, buried intertextually in a citation of Saint James' Epistle: "Ut Jacobus ait Apostolus." 25 James 5:1 1 cites Job as an outstanding example of patience and a proof of God's providential care. Petrarch, however, does not name Job but rather paraphrases James $1: 13$ to assert that God only permits us to be tested by evils, while he himself puts no one to the test: "et ipse neminem temptet." 26

Petrarch's Walter is enigmatic, his genuine benevolence toward Griselda hidden from her as he tests her, removing from her first her infant daughter, then her son, apparently to kill them; divorcing her and then recalling her to prepare the hall for his new bride. Petrarch's Griselda is equally enigmatic, her feelings veiled in her steadfast submission to Walter's will and God's: "Deo et tibi gratias ago." 27 Thus Petrarch's rendition of the story makes it a Stoic and Boethian allegory of God's providential action. As Chaucer's Clerk explains, God, like Walter, "suffreth us, for oure exercise, / With sharpe scourges of adversitee / Ful ofte to be bete in sondry wise" (lines 1 156-58), but "for oure beste is al his governaunce" (line $1161) .{ }^{28} \mathrm{We}$, therefore, ought to live "in vertuous suffraunce" (line

23. Morse, "Exemplary Griselda," p. 57. See also Charles Trinkhaus, The Poet as Philosopher: Petrarch and the Formation of Renaissance Consciousness (New Haven: Yale University Press, 1979).

24. Morse, "Exemplary Griselda," p. 58.

25. William F. Bryan and Germaine Dempster, eds., Chaucer: Sources and Analogues (1941; New York: Humanities Press, 1958), p. 330.

26. After examining over sixty manuscripts of Petrarch's Latin story of Griselda, J. Burke Severs found an explicit mention of Job in only one fifteenth-century manuscript. See "The Job Passage in the Clerkes Tale," MLN 49 (1934): 461-62.

27. Bryan and Dempster, Chaucer: Sources, p. 320.

28. Geoffrey Chaucer, "The Clerk's Tale," in Larry Benson, gen. ed., The Riverside Chaucer, $3 \mathrm{~d}$ ed. (Boston: Houghton Mifflin, 1987). All quotations from the tale are cited parenthetically by line number. Quotations from Chaucer's other works are also taken from this edition and similarly cited. 
1162 ) of God's wish and will and "be constant in adversitee / As was Grisilde" (lines $1146-47$ ).

Petrarch clearly tells Griselda's story to inspire imitation. As Morse notes, however, "Petrarch never explains how anyone musters the spiritual or psychological strength to imitate Griselda." 29 Chaucer supplies that lack, represented in Petrarch's "comparative absence of Christian reference," by adding a series of biblical allusions in his tale of Griselda. ${ }^{30}$ In the process, as J. Burke Severs observes, Chaucer makes "significant changes in characterization, in narrative technique, and in the tone and spirit which informs the tale." 31 The biblical allusions complicate and counter Petrarch's Boethian allegory by letting the revealed truth of theology answer to philosophy, the Bible to Boethius. ${ }^{32}$

In "The Clerk's Tale" Griselda is constantly described in an evocative manner that likens her to Christ; to the Virgin Mary at the Annunciation hour, in Bethlehem, at Cana, and at the foot of the cross; and, thirdly, to suffering Job. Whereas "Men speke of Job, and moost for his humblesse" (line 932), the Clerk sings the praises of Griselda, whose patience exceeds that of Job. Divorced, divested of her royal clothes, and dismissed from the palace, Griselda echoes Job's speech: “ 'Naked out of my fadres house,'” quod she, / 'I cam, and naked moot I turne agayn'" (lines $871-7^{2}$ ).

Griselda's Joban silence and pointedly controlled, two-edged speech (which hints at her true feelings) contrasts with the despair of her father who, like Job in the presence of his consolers, "curseth the day and tyme that Nature / Shoop hym to been a lyves creature" (lines 902-3). ${ }^{33}$ Similarly, her heroic endurance of psychological torment contrasts with the emotive commentary of the male Clerk-

29. Morse, "Exemplary Griselda," p. 8o.

3o. Ibid., p. 58 .

31. J. Burke Severs, “The Clerk's Tale," in Bryan and Dempster, Chaucer: Sources, p. 290.

32. Jane Chance notes a similar tension in Chaucer's lyrics. See "Chaucerian Irony in the Boethian Short Poems: The Dramatic Tension Between Classical and Christian," Chaucer Review 20.3 (1986): 235-245. Chance suggests that the contrast between the poems' "Boethian problem" and their "Christian (Augustinian) solution" actually extends the "doubleness ... found in Boethius, given the double-nature of the protagonist, dispirited and desperate at the beginning of the Consolation and calm and rational at the end" (p. 243).

33. Cf. Besserman, Legend of Job, p. 112. 
narrator, who sympathizes with Griselda in her plight and denounces Walter as diabolic, decrying his cruelty and needless testing of her virtue.

The biblical allusions and the narrative intrusion of Chaucer's Clerk accomplish two purposes. Chaucer not only creates in Walter's wife, Griselda, a Joban wife in answer to the clerical mysogyny that demonizes the biblical wife of Job and her counterpart, the nagging and seductive Wife of Bath. His version of the story also systematically undermines and redirects the Petrarchan allegory. ${ }^{34}$ Griselda becomes the divine figure, Walter the demonic; Griselda, the redeemed and redeeming figure, Walter the one in need of redemption. Like the Gregorian Job, Griselda is "constant in adversitee" (line 1146 ), but hers is not the constantia mentis of a Stoic philosopher, but the constantia amoris of a saint. She suffers Christ's passion, converts her sadistic husband, and accomplishes genuine change in him and others through a divine (indeed, Incarnational) acceptance of mutability. Her patience, as Morse insists, has "positive power."35

The simultaneous confluence and opposition of Boethian and Joban themes that characterizes "The Clerk's Tale" also marks Chaucer's rendition of the Constance romance. ${ }^{36}$ In "The Clerk's Tale" Chaucer signals the tension between philosophy and theology by the Clerk's self-conscious remarks about his indebtedness to and departure from his Petrarchan source. In "The Man of Law's Tale," as we shall see, a similar tension emerges from the teller's struggle with the mixture of romance and hagiography in the tale as his

34. I argue both propositions in "Job's Wife, Walter's Wife, and the Wife of Bath," in Old Testament Women in Western Literature, ed. Raymond-Jean Frontain and Jan Wojcik (Conway: University of Central Arkansas Press, 1991), pp. 92-107. See also my. "Translating Job as Female," forthcoming in Translation Theory and Practice in the Middle Ages, ed. Jeanette Beer (Kalamazoo, Mich.: Medieval Institute Publications).

35. Morse, "Exemplary Griselda," p. 52. She cites Ralph Hanna, "Some Commonplaces of Late Medieval Patience Discussions: An Introduction," in Gerald J. Schiffhorst, ed., The Triumph of Patience: Medieval and Renaissance Studies (Orlando: University Press of Florida, 1978), pp. 67-70.

36. Margaret Schlauch surveys analogues of the Constance story in Chaucer's Constance and Accused Queens (New York: New York University Press, 1927). The tale of Constance has strong affinities to Hellenistic romance. See Elizabeth Archibald, "The Flight from Incest: Two Classical Precursors of the Constance Theme," Chaucer Review 20.4 (1986): 259-72; P. H. Goepp, "The Narrative Material of Apollonius of Tyre," ELH 5 (1938): 150-72. 
"wisdom" falls short of the Pauline "foolishness" of his heroine. ${ }^{37}$ Even as Chaucer splits the figure of Job in "The Clerk's Tale" to create the silent Griselda and her cursing father Janicula, he sets the Boethian apostrophe of the Man of Law, as he narrates the vagaries of fortune, against the Joban prayer of Custance, as she answers to Providence. Out of this juxtaposition Chaucer fashions a subtle satire that calls into question not only the wisdom of the Man of Law but also the impulse to romanticize sanctity.

\section{Apostrophe, Prayer, and the Structure of Satire in "The Man of Law's Tale"}

"The Man of Law's Tale" has figured prominently in the ongoing debate about the teller-tale relationship in The Canterbury Tales. ${ }^{38}$ Is "The Man of Law's Tale" primarily a satire exposing the hypocrisy of its pilgrim narrator? ${ }^{39} \mathrm{Or}$ is it a pious legend about its saintly heroine,

37. The General Prologue portrait of the Sergeant of the Law emphasizes his wisdom. "[W]ar and wys" (GP 309), the Sergeant impresses the pilgrim Chaucer as a man of discretion and reverence: "his wordes weren so wise" (GP 313 ).

38. Pointing to the tenuous relationship between the headlink, the "poverty prologue," and the pious legend in rhyme-royal stanzas, Bernard F. Huppé and others have insisted that "the Tale must speak for itself without regard to its particular dramatic setting or its narrator." See Huppé, A Reading of the Canterbury Tales (Albany: State University of New York Press, 1964), p. 96. See also John Tatlock, "The Man of Law's Tale," in The Development and Chronology of Chaucer's Works (Gloucester: Peter Smith, 1963), pp. 172-88. Arguing on different grounds, David Lawton, in Chaucer's Narrators (Cambridge: D. S. Brewer, 1985), has insisted that "lines using a narratorial ' $I$ ' in the body of any of the tales cannot be used to demonstrate a point about the ostensible teller" (p. 104). Observing that the narrator's voice in all of Chaucer's "high-style" stories (including "The Man of Law's Tale") is virtually the same (pp. 76-105), Lawton restricts the applicability of speech-act theory to the prologues of tales, excluding the tales themselves (p. 4). C. David Benson makes an argument similar to Lawton's in "Their Telling Difference: Chaucer the Pilgrim and His Two Contrasting Tales," Chaucer Review 18 (1983): 61-76. H. Marshall Leicester, Jr., in "The Art of Impersonation: A General Prologue to the Canterbury Tales," PMLA 95 (1980): 213-24, was among the first to discredit the dramatic model by shifting emphasis away from the voices of pilgrims to the voicing of the tales themselves.

39. For excellent treatments of the appropriateness of the tale's assignment to the Man of Law as a satiric object, see Warren Ginsberg, The Cast of Character: The Representation of Personality in Ancient and Medieval Literature (Toronto: University of Toronto Press, 1983), pp. 144-51; Roger Ellis, Patterns of Religious Narrative in the "Canterbury Tales" (Totowa, N.J.: Barnes and Noble Books, 1986), pp. 119-68; Alfred David, "The Man of Law versus Chaucer: A Case in Poetics," PMLA 82 (1967): $217^{-}$ 
more properly called "The Tale of Custance"? The historical division of critics into two camps suggests that auditors are hearing two different voices in the tale, the narratorial "I" isolated as direct discourse and the oppositional "I" of Custance herself as a speaking subject.

Chaucer's additions to his source, Nicholas Trevet's AngloNorman Chronique, chiefly consist of (1) apostrophe, exclamatio, and rhetorical questions interjected by the narrator, and (2) prayers uttered by Custance. ${ }^{40} \mathrm{I}$ argue that Chaucer's additions effectively convert a saint's legend into a satire through the systematic opposition of two rhetorical figures-apostrophe (assigned to the narrator) and prayer (assigned to Custance) - that punctuate the unfolding plot line and provide a divergent commentary on the events being related. ${ }^{41}$ Not only does Chaucer oppose the viewpoints of the tale's heroine and her pilgrim narrator in a conflictus of providential and fatalistic orderings of experience, but he assigns to each a characteristic figura that has its proper sign value, its power to define not only the individual personae as such, but also the differences between them. Custance's prayers do more than characterize her as a saint. As direct discourse they give Custance a voice and personal genre, allowing her to speak for herself and thus provide a counterinterpretation of events otherwise related to the audience only by the shortsighted narrator.

\section{Apostrophic Narration}

The tale itself is episodic, its story line punctuated by five sea voyages, its chronology spanning all of Custance's adult life, the setting for its action changing from Rome to Syria to England and

25; Chauncey Wood, “Chaucer's Man of Law as Interpreter," Traditio 23 (1967): 149-9o.

40. The best source study is E. A. Block's “Originality, Controlling Purpose and Craftsmanship in Chaucer's 'Man of Law's Tale,'” PMLA 68 (1963): 572-616.

41. Satire derives from the word satura, "full plate," denoting a medley or mixture of fruits. The opposition of prayer and its converse, apostrophe, establishes a medley enabling the exposure of the Man of Law as a self-important philosophus gloriosus, a common target in the tradition of Menippean satire. See Northrop Frye, Anatomy of Criticism: Four Essays (New York: Atheneum, 1969), pp. 309-12; F. Anne Payne, Chaucer and Menippean Satire (Madison: University of Wisconsin Press, 1981). See also n. 2 above. 
back again. The natural division of the tale into discrete episodes lends itself to narrative intrusion and provides ample opportunity for the teller to interject a stylized, pathetic, or moral-didactic commentary on Custance's long-suffering, which reflects, in turn upon his character and understanding of the story. He responds to the tale he tells in a series of sentimental outbursts typically beginning with a rhetorically charged "O": "O firste moevyng! Crueel firmament" (MLT 295-315); "O Sowdanesse, roote of iniquitee!" (lines 358$71)$; "O sodeyn wo" (lines 421-27); "O my Custance" (lines 44648); "Who saved Danyel" (lines 473-504); "Allas! Custance, thou hast no champioun" (lines 631-37); "O queenes, lyvynge in prosperitee" (lines 652-58); "O messager, fulfild of dronkenesse" (lines 771-77); “O Donegild" (lines 778-84); “O my Custance" (lines 803-05); "O foule lust of luxurie" (lines 925-31); "How may this wayke womman" (lines 932-45); "But litel while it lasteth, I yow heete" (lines $1132-41$ ). The apostrophe marks the narrator's distinctive style, defines his voice, articulates his worldview, and sets him apart (in the reader's awareness) from the tale he tells and its characters whose voices, recorded in direct discourse, remain distinct from the narrator's own.

Unlike prayer which, by definition, addresses itself to One unseen but intimately present, apostrophe invariably addresses the Absent One. As such, apostrophe is a rhetorical trope suited to a world view that is essentially anthropocentric, rather than providential. Indeed, absence and abandonment belong to the very definition of the form and explain its frequent occurrence in tragedy. In "The Man of Law's Tale" apostrophe is more than a figure of speech. Repeated and extended throughout the narrative, it becomes a figure of thought ("sic hoc schema faciat tropos ille textus") indirectly revelatory ("apparens magis quam confessa") of the speaker's whole perspective on things. ${ }^{42}$

While the narrator's speech generally (though not always) follows a horizontal line in his moral-didactic addresses to the audience and pathetic exclamations to his characters ("O my Custance"), the voice

42. Quintilian, Institutio Oratoria 9.2, vol. 3, trans. H. E. Butler, Loeb Classical Library (Cambridge: Harvard University Press, 1921 , 1943), p. 40o. Quintilian gives the example of Socrates, whose all-pervasive use of irony essentially defined his worldview "cum etiam vita universa ironiam habere videatur." 
of his heroine follows a distinctly vertical line. Her characteristic genre is not apostrophe but prayer: " 'O cleere, o welful auter, hooly croys' " (lines 451-62); "Immortal God, that savedest Susanne'" (lines 639-44); “'Lord, ay welcome be thy sonde!' " (lines 826-33); " 'Mooder, ... and mayde bright, Marie'" (lines 841-61). Piety with its vertical impulse also distinguishes her other recorded speeches-

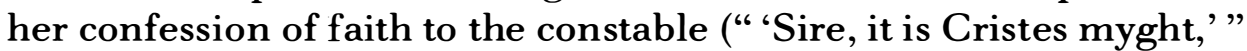
line 570), her words of comfort to her babe (" 'Pees, litel sone,'" line 836), her welcome to her father ("Fader, . . . youre yonge child Custance," "line 1 105). Custance herself speaks so seldom, simply, and movingly that her utterance, in dialogue with the narrator's selfconsciously rhetorical outbursts, effectively exposes the shallowness of his interpretation. From within the tale she responds to its successive events in a way that contrasts sharply with the narrator's commentary on that same narrative unfolding. Custance's vertical discourse intersects with his horizontal speaking, and the sounding of the two voices enables Chaucer to make his satiric point as poet without appropriating either voice as his own.

The narrator's own explicit and arbitrary division of the tale into three parts-pars secunda beginning at line 386 and pars tercia beginning at line 876 - shows his ignorance of literary-logical criteria for marking sections in a narrative. Indeed, the narrator remains so much on the periphery of the tale he tells that he misconstrues its genre. He treats the story of Custance as if its heroine were simply a wronged woman whose pathetic plight and high birth liken her to Lucrece, Thisbe, Dido, Phyllis, Ariadne, Hypsipyle, Hero, Helen, and the other ill-fated women whose woeful stories appear in Ovid's Heroides and Chaucer's own Legend of Good Women. He explicitly compares the weeping over Custance's fate to the general lamentation over the falls of Rome, Troy, and Thebes (lines 288-94). Whatever the textual problems involved in connecting the headlink with the tale that follows it, the narrator's apostrophic, overly pathetic commentary on the tale of Custance is generically more appropriate to a "Seintes Legende of Cupide" (line 61) than to hagiography. Thus the tale, to the extent that it is a saint's life, incriminates the teller, whose responses to his own heroine are consistently inapt.

In adopting an apostrophic mode of commentary on the events in Custance's life, the narrator appropriates for himself the basic genre 
of the Heroides. While the utterances of Ovid's abandoned women in love take an epistolary form, they are essentially apostrophic (in the Ciceronian sense of that term) in that they address an absent person from whom no reply is expected and serve to express the speaker's grief or indignation: "Exclamatio est quae conficit significationem doloris aut indignationis alicuius per hominis aut urbis aut loci aut rei cuiuspiam conpellationem." ${ }^{43}$ Indeed, the loss of husband and/ or lover-an irretrievable "absence" that turns a letter into a lament ("querela") — frequently undermines the status of the speaking subject. Unable to call the beloved into presence, the voice of the heroine replaces itself with the mute speech of an epitaph. Phyllis closes her letter to Demophoon with the inscription destined for her sepulcher: "Phyllida Demophoon Leto Dedit Hospes Amantem; / Ille Necis Causam Praebuit, Ipsa Manum" (lines 1 47-48). ${ }^{44}$ Dido's last words to Aeneas are the words of her marble tomb: "Praebuit Aeneas Et Causam Mortis et Ensem; / Ipsa Sua Dido Concidit Usa Manu" (lines 195-96). ${ }^{45}$ Hypermnestra, too, closes with her own funereal epitaph. Similarly, the epistles of Briseis, Hermione, Deianira, Ariadne, Canace, and Medea end with notices of impending death. Apostrophe (the address to the absent) thus turns into prosopopoeia (speech of the absent, dead, inanimate), one figure dissolving into its inverse.

When the Man of Law adopts the apostrophic mode that Ovid reserves for his female speakers, he redefines the function of the rhetorical figure. The narrator's apostrophe differs from the exclamatio of his tale's heroine in that it expresses not his own grief or indignation but his power to compassionate with Custance-she who is his persona in the double sense of a fictive creation and a defendant entrusted to his advocacy. ${ }^{46}$ Apostrophe thus becomes

43. Cicero, Rhetorica ad Herennium 4.15.22, trans. Harry Caplan, Loeb Classical Library (Cambridge: Harvard University Press, 1954, 1981), p. 282. Cicero gives the example of an address to the elder Scipio Africanus, "whose name even in death means splendor and glory to the state."

44. Ovid, Heroides and Amores, trans. Grant Showerman, 2 d ed. rev. G. P. Goold, Loeb Classical Library (Cambridge: Harvard University Press, 1914, 1977 ), p. 30.

45. Ibid., p. 98.

46. Alain de Lille notes that "persona" is a technical term for a client or defendant in a court case: "Apud rhetorem etiam persona dicitur qui propter suum factum vel dictum vel suas possessiones trahitur in causam, unde: Artis rhetoricae materia sunt persona et negotium," Liber in distinctionibus dictionum theologicalium, PL 21 o, c899. For an excellent discussion of the varied usages of the word, see Robert C. Elliott, 
self-reflexive, the mark of his own "gentilesse," "pitee," and erudition. In the context of his self-appointed status as a literary critic, the "O" of the Man of Law signals not only his gravitas as a judicial orator but also his ambition to rival Chaucer as an Ovidian imitator (lines 91-96):

"Me were looth be likned, doutelees, To Muses that men clepe PieridesMethamorphosios woot what I mene; But natheless, I recche noght a bene Though I come after hym with hawebake.

I speke in prose, and lat him rymes make."

The Man of Law exposes the false humilitas of his disclaimer both by insulting Chaucer, who, he says, "kan but lewedly / On metres and on rymyng craftily" (lines $47-48$ ), and by turning immediately "with a sobre cheere" (line 97) to his own apostrophic prologue: "O hateful harm, condicion of poverte!" (line 99 ). ${ }^{47}$

\section{Apostrophic Irony}

Chaucer proceeds to turn the narrator's use of the figura against him so that it signifies not his wisdom but his windiness. In Poetria nova (c. 121 o) Geoffrey de Vinsauf follows the apostrophic lament on the death of Richard I (which he gives as an example of the form, and which Chaucer puts to mock-heroic use in "The Nun's Priest's Tale") immediately with a discussion of verbal irony used against the philosophus gloriosus-the "ape among the learned doctors" who "flaunts himself." 48 The inclusion of this kind of irony ("carried by ridicule against ridiculous men") under the heading of apostrophe

“The Word Persona," in The Literary Persona (Chicago: University of Chicago Press, 1982), pp. 19-32.

47. Ginsberg (The Cast of Character) remarks that "there seems to have existed a traditional animus between lawyers ... and poets" (p. 149), citing Horace, Ovid, Virgil, and Boccaccio (see pp. 147-50). The inconsistency between the Man of Law's stated intent to speak in prose and the actual casting of the tale in rhyme royal stanzas may be an intentional Chaucerian allusion to prosimetrum, the mixed form traditionally associated with Boethius and Menippean satire.

48. Geoffrey of Vinsauf, Poetria nova, trans. Jane Baltzell Kopp, in James J. Murphy, ed., Three Medieval Rhetorical Arts (Berkeley: University of California Press, $1971)$, p. 50. 
seems to indicate that the misuse of the trope by windy speakers inevitably exposes them to satiric treatment by others-that the form itself, as Geoffrey says, "may change her face."

Geoffrey's classification, at any rate, reflects the classical use of apostrophe as a satiric means. As Martin Winkler has shown, both Cicero (in his comic impersonation of Appius Claudius Caecus as a gravis persona) and Juvenal (in his Satire 14 prosopopoeia of an indignant ancestor) were well aware that an overuse of Grand Style tropes works to make a speaker ridiculous, and they used it accordingly, allowing the self-important objects of their satire to lay bare their own pomposity. ${ }^{49}$ The Roman satirists clearly capitalize on the failure of their personae to heed the standard textbook recommendation to use it in its proper place ("loco"), rarely ("raro"), and only when the importance of the subject seems to demand it ("cum rei magnitudo postulare videbitur") for the sake of instilling indignation. ${ }^{50}$

Geoffrey's close association of apostrophe with irony directed against pretentious men of learning strongly enforces the idea that the exclamatory narrative voice we are hearing in "The Man of Law's Tale" is simultaneously creating the persona of the speaker and exposing his emptiness. ${ }^{51}$ If, as Warren Ginsberg has shown us, "the foremost supposition of Roman rhetoric is that the style and tone of any speech reflect the character of its speaker" according to the principle "ut quasi mores oratoris effingat oratio," then the apostrophe as figura must be taken seriously as the character-literally, the mark ("notatio") — of the Man of Law. ${ }^{22}$ In this context David Lawton is

49. Martin M. Winkler, "Juvenal's Attitude toward Ciceronian Poetry and Rhetoric," Rheinisches Museum für Philologie, vol. 131, no. 1 (Frankfurt am Main: J. D. Sauerlander, 1988), pp. 84-97. Winkler has argued more recently not only that "Grand Style is ... one of the chief features of Juvenalian satire" but also that Juvenal's is "an epic satire, i.e., satire delivered largely in the epic style." See "The Function of Epic in Juvenal's Satires," Studies in Latin Literature and Roman History, vol. 5, ed. Carl Deroux (Brussels: Latomus Revue d'Études Latines, 1989), pp. 414-43.

50. Cicero, Ad Herennium 4.15.22, p. 284.

51. Eugene Vance rightly observes that the "rhetor" in Chaucer "is usually seen as a powerful and dangerous figure who subverts the well-being of society,". citing as examples the Summoner, the Pardoner, and the Wife of Bath. See Marvelous Signals: Poetics and Sign Theory in the Middle Ages (Lincoln: University of Nebraska Press, 1986), p. 264 .

52. Ginsberg, The Cast of Character, p. 17. See Cicero, De oratore, trans. E. W. Sutton and H. Rackham, vol. 1, Loeb Classical Library (Cambridge: Harvard University Press, 1942), II.xliii. 184 , p. 328. 
right when he says that "the 'I' is integral of the exclamatio." 53 The speech necessarily creates a speaker-in this case a speaker whose persona matches, even as it colors and qualifies, the third-person portrait of the lawyer in the "General Prologue." As Ginsberg has suggested, "The Canterbury pilgrims are twice-formed at least, once by the tales and once by their frame," 54 but the techniques of characterization are different. ${ }^{54}$ When narrative voice works to characterize the fictive speaker, the style literally makes the Man of Law.

Chaucer seldom uses the word "style," and when he does he associates it specifically with "heigh style." 55 "Manere," on the other hand, is a favorite expression of his, and he employs it frequently to mediate between a wide variety of literary and character types, linking them as modus and mos. ${ }^{56}$ Chaucer assures us, for instance, that the Miller "tolde his cherles tale in his manere" (MilP $3_{169}$ ), while the Monk bewailed his histories "in manere of tragedie" (MkT 1991). Chaucer's conscious effort to harmonize the discourse and social behavior ("cheere") of his characters, "as techeth art of speche hem that it leere" ( $S q T$ 1 04), aligns him with a long rhetorical tradition that emphasized decorum in impersonation. ${ }^{57}$ Whether that impersonation takes the form of ethopoeia (soliloquy), prosopopoeia, or sermocinatio (dialogue), the principle remains the same: "personae oratio accommodata ad dignitatem." 58

\section{Apostrophe and Prayer}

The apostrophic voicing of "The Man of Law's Tale" must be considered a comment on its narrator. None of the other tales that most resemble it in plot (as some kind of female saint's legend) "The Clerk's Tale" of patient Griselda, "The Second Nun's Tale" of Saint Cecilia, "The Physician's Tale" of Virginia-exhibits the in-

53. Lawton, Chaucer's Narrators, p. $9^{2}$.

54. Ginsberg, The Cast of Character, p. 164.

55. The Concordance lists only four instances - three of them in "The Clerk's Tale" (lines 18, 41, 1 148) and one in "The Squire's Tale" (lines 105-6).

56. There are six full columns of entries in the Concordance. The entries in both the Middle English Dictionary and the Oxford English Dictionary show that the sense development of "manner" reflects its assimilation to modus and mos as literary and social terms.

57. See Henrik Specht's magisterial article, “'Ethopoeia' or Impersonation: A Neglected Species of Medieval Characterization," Chaucer Review 21.1 (1986): 1-15. 58. Cicero, Ad Herennium 4.43.55, p. 366. 
trusive "O" of narratorial apostrophe or even assigns apostrophic speeches to their heroines. Indeed, the seeming busyness of the Man of Law contrasts sharply with the genuine industry of the Second Nun, who translates the Cecilia legend in plain style. The omission of apostrophe seems to reflect the Augustinian emphasis on sermo humilis, revived in Chaucer's own time by Wyclif, who generally counseled the avoidance of "heroic declamation" as a form inappropriate to the subject and aim of religious writing: "Sed non dubium quia plana locucia de pertinentibus ad salutem sit huius modi, ideo illa est eligenda declamatione eroyca postposita." 59 Indeed, Wyclif's wellknown insistence on the plain style may help explicate the Host's call in the Epilogue for a Lollard ("Lollere") to tell a tale in answer to the Man of Law's apostrophic narrative.

Prayer and apostrophe, as converse figurae, remain at odds. Chaucer chiefly reserves apostrophic utterance for characters who are facing an experience of loss from a fortune-oriented perspective: Arcite's apostrophe to the absent (because imprisoned) Palamon and distant Emily (KnT 1223-74), Palamon's apostrophe to the absent (because released) Arcite (KnT 1281-1333), Dorigen's plaint to Fortune (FranT 1355-1456), Apollo's lament over his dead wife (ManT 274-91), Troilus' multiple plaints over Criseyde's exchange (TC 4.250-336), Criseyde's parallel apostrophe to Troilus $(4 \cdot 743-98){ }^{60}$

When Chaucer's narrators employ the figure, they invoke the tradition of the strumpet muses dismissed from Boethius' prison cell who "fedyn and noryssen" (Boece 1, pr. 1.52-53) his sorrow by inspiring "drery vers of wretchidnesse" (Boece 1, m. 1.5-6). Boethius begins writing his Consolatio as a weeping narrator, his face wet with "verray teres" (line 6). His initial stance is replicated in the apostrophic narratorial commentary on tragedies provided by the weeping narrator of Troilus, the Monk ("O noble, O worthy Petro!" MkT 2375), the Merchant acquainted with "wepyng and waylyng" ("O sodeyn hap! O thou Fortune unstable!" MerP 1213 , MerT 2057) and the tongue-in-cheek Nun's Priest with his mock-heroic exclamationes: "O false mordrour lurkynge in thy den! / O newe Scariot,

59. Quoted by Ginsberg in his discussion of "The Clerk's Tale" in The Cast of Character, p. 161 .

6o. For a general survey of Chaucerian apostrophe, see John Nist, "Chaucer's Apostrophic Mode in The Canterbury Tales," TSL 15 (1970): 85-98. 
newe Genylon" (NPT 3226-27); "O destinee, that mayst not been eschewed!" (line 3338); "O Venus" (line 3340); "O Gaufred" (line 3347); "O woful hennes!" (line 3369).

The other two narrators of tales who call attention to themselves with apostrophic commentary are, of course, the Pardoner and the Prioress. The Pardoner prides himself on his theatrical performance and sophistic, oratorical skills, and his specific use of apostrophe"O glotonye, ful of cursednesse!" (PardT 498), "O womb! O bely! O stynkyng cod" (line 534), "O cursed synne of alle cursednesse!" (line 895)-underscores his avaricious preoccupation with material goods. He apostrophizes avarice in its various forms to distance himself from it rhetorically and thus detach his audience from their money: "for to make hem free / To yeven hir pens, and namely unto me" (lines 401-2).

The Prioress, for her part, assimilates her apostrophic " $O$ " to the vocative "O" of "O Alma Redemptoris Mater"-even as she represents her tale-telling in her prologue as a "song" (line 487). With the single exception of "O cursed folk of Herodes" (line 574), all of her apostrophes could superficially be considered prayers addressed, as they are, to God and his saints: "O martir, sowded to virginitee" (line 579); “O grete God” (line 6o7); “O yonge Hugh of Lyncoln, slayn also" (line 684). Indeed, the troubling thing about the Prioress' narration is that she uses the language of religious presence (prayer) in a way that makes God absent, her violent anti-Semitism negating the mercy she invokes. Blessing and curse mingle in her discourse. The "cursed folk" (line 574) of her single apostrophe becomes the "cursed" Jews of her echoic narrative (the epithet is repeated in lines $578,599,63^{1}$, and 685), even as her story renders them absent through the vehicles of ghetto, death, and historical expulsion. ${ }^{61}$ The Prioress' stance distances herself from both the Jews she curses and the God of Mercy she invokes. She, in effect, turns prayer (the address to One present but unseen) into apostrophe (the direct address of One who is not there), one figure merging into its converse.

Custance, on the other hand, never confuses the two. Her prayer dramatizes a perfectly appropriate response to her perilous circumstances and thus reifies the meaning of the figure. Medieval treatises

61. The murder of Hugh of Lincoln contributed to the expulsion of the Jews from England in 1290. 
on prayer define the word in its root meaning: precari, "to beg," "to entreat"; orare, "to plead a case." Hugh of Saint Victor, for instance, insists that prayer arises out of the human heart with a primal force whenever a person experiences calamity: "Quid enim efficacius hominem orandi studium excitaret quam miseria et calamitas tantorum malorum, quibus addictus premitur?" $62 \mathrm{He}$ prescribes, as a necessary preparation for prayer, meditation on the miseries of the human condition:

Cogitemus quam brevis sit vita nostra, quam lubrica via, quam mors incerta. Cogitemus quod lugentes in hanc vitam intravimus, cum dolore pertransimus, cum luctu exituri sumus. Cogitemus quantis amaritudinibus admistum sit, si quid etiam dulce aut jucundum in via hujus vitae occursu suo nobis alludit. ${ }^{63}$

[Let us consider how brief our life is, how slippery our way, and how unpredictable, death. Let us recall that we enter into this life wailing, pass through it with sorrow, and leave it with lamentation. Let us think about how mixed with bitterness everything is, if indeed we happen to experience anything sweet or pleasant on life's path.]

Chaucer's English contemporaries urge the same existentialist basis for prayer. The author of $A$ Pistle of Prayer advises the person who prays to impress upon himself in graphic terms the immediacy of his own death so that every prayer has the force of the last: "it schuld be ful speedful to pee at pe first biginnyng of pi preier, what preier soeuer it be, longe preier or schort, for to make it ful knowen to pin hert wipouten any feinyng bat pou schalt dize in pe ende of pi preier, and, bot bou spede pee pe raper, er bou come to pe ende of pi preier." ${ }^{44}$ Similarly, Walter Hilton encourages the subject of human need, suffering, and mortality as an appropriate topic for meditation, noting that the consideration of human misery typically culminates in a sincere prayer of petition: "Also for to penke of pe wrecchidnesse, myscheues and perils, bodili and goostli, pat fallen in pis liyf, and aftir pat for to penke of pe ioies of heuene, hou moche blisse pere

62. Hugh of St. Victor, De modo orandi, PL 176 , c977.

63. Ibid. The translation is mine.

64. "A Pistle of Preier," in Phyllis Hodgson, ed., The Cloud of Unknowing and Related Treatises (Salzburg: Institut für Anglistik und Amerikanistik, 1982), p. 101. 
and ioie ... pe more bat pou penkist and felist pe wrecchidnes of pis lijf, pe more feruentli schal pou desire pe ioie and pe reste of be blisse of heuen." 65

The process outlined in the manuals of prayer finds its narrative parallel in the story of Custance and in the reader who considers her misery. Her vita embodies the miseria of the papal text invoked by the prologue to the tale: Innocent III's De contemptu mundi (or, as Chaucer entitles it in his translation, "Of the Wretchede Engendrynge of Man Kynde"). The episodes of her perilous existence are punctuated with prayers of petition, entreaty, and self-surrender to God's will. The reader, drawn into her story-which reads like a Perils-ofPauline summa of everything bad that can happen ("calamitas tantorum malorum") —is actually involved in a meditation on the very topic most conducive to prayer ("miseria") and thus stimulated to appropriate her utterance. The ego of the one who prays is, as Patrick Diehl would say, paradigmatic_-an "open" ego inviting a communal voicing. ${ }^{66}$ Custance, in short, is impersonated by prayer as a figure of speech and becomes herself personified prayer. To use a phrase from Eugene Vance, the "poetics" of Custance's sign (prayer) essentially defines her, even as it directs our response to her story. ${ }^{67}$

Custance's saintliness, her exemplary utterance, and her symbolic femininity (with its power to represent the soul in its relationship to God) exert a centripetal force on the auditors, who are drawn into identification with her as the embodiment of their communal ideal. As Alison Goddard Elliott has observed about the martyrs' passiones, and saints' legends in general, the direct discourse of the saintswhatever its simple locutionary force within the dramatic contexthas an additional illocutionary power on its hearers as they appropriate the sentiments of their models in faith. ${ }^{68}$

This primary rhetorical movement into the text is opposed by the centrifugal, masculine impulse of the voice of the narrator, whose

65. S. J. Ogilvie-Thomson, ed., Walter Hilton's "Mixed Life," Edited from Lambeth Palace $M_{472}$ (Salzburg: Institut für Anglistik und Amerikanistik, 1986), pp. 58-59.

66. Cf. Patrick S. Diehl, The Medieval European Religious Lyric: An Ars Poetica (Berkeley: University of California Press, 1985), pp. 141, 158.

67. Cf. Vance, Marvelous Signals, pp. 258-63.

68. Alison Goddard Elliott, "The Power of Discourse: Martyr's Passion and Old French Epic," in Paul Maurice Clogan, ed., Medievalia et Humanistica, n.s. 11 (Totowa, N.J.: Rowman and Littlefield, 1982), pp. 39-6o. 
overt sympathy for Custace and expressed desire to intervene actively on her behalf oppose true identification with her, imitation of her action, and simple acceptance of her story at every step of its providential unfolding. Unlike Custance, who regards her own life story as a sequence of divine initiatives, of sendings on God's part and acceptance on hers, the lawyer regards the pattern of events to be an inevitable alternation of "wo" and "joy" based not on God's providential design but on the turning of fortune's wheel. Indeed, the Boethian distinction between providence and destiny essentially defines the differences between Custance's perception of things and that of the Man of Law. The strumpet muses of tragedy inspire the Man of Law, as a weeping narrator, to speak apostrophically, while Custance draws her inspiration elsewhere.

\section{Custance and the Man of Law}

Custance's first speech (lines 274-87), addressed to the Roman emperor, is more than a young girl's tearful farewell to her father, and more than an adolescent's worldly-wise acceptance of the facts of life-although the narrator interprets it as such (lines $267-73$ ). $\mathrm{Cu}$ stance feels keenly the pain of parting from her parents, but she recognizes her lot as a consequence of original sin-"Women are born to thraldom and penance, / And to been under mannes governance" (lines 286-87)-and almost instinctively joins her suffering to that of "Crist, that starf for our redempcioun" (line 283). She subordinates destiny to providence, consenting to the marriage arranged by her father and the Sowdan as a way of obeying God: "So yeve me grace his heestes to fulfille" (line 284). At the beginning of the tale Custance already entrusts herself to the "devyne myght" (Boece 4, pr.6.337) who ultimately governs the world and who has the power to bring good even out of evil. Custance's "yes" to the will of God as revealed through secondary causes (in this case her father and the Sowdan) expresses her belief that "no thing nis withouten ordenaunce in the reame of the devyne purveaunce" (Boece 4, pr.6.349-51).

Custance's speech is followed almost immediately by three stanzas (lines 295-315), not found in Trevet, in which the narrator bewails the fact that Custance's departure coincides with an aberration in the 
ascendancy of the planet Mars. Unlike Custance, the Man of Law makes no distinction between providence and destiny. Instead he practically identifies God with fate, the First Mover with the "firste moevying" (line 295) of the primum mobile. His blasphemous address to the "crueel firmament" (line 295) directly contradicts the Christian belief, expressed by Lady Philosophy in Chaucer's Boece, that God's "love ... governeth erthe and see, and hath also comandement to the hevene" (Boece 2, m.8.15-16). Indeed, the Man of Law's speech echoes the unenlightened complaint of Boethius before his instruction by Lady Philosophy: "O thow makere of the wheel that bereth the sterres" (Boece 1, m.5.1-2).

The narrator's commentary on the events in Syria, like his interpretation of Custance's farewell and departure, reveals a thoroughly fatalistic way of looking at things. In his exclamations against the Sowdaness he associates her so closely with Satan that she (like the Jews in "The Prioress's Tale") loses all humanity and, therefore, all freedom to make moral choices. Like Donegild, she becomes a "feyned womman" (line 362), evil by nature, who necessarily brings forth "iniquitee" (line $35^{8}$ ). The massacre at the wedding feast is similarly glossed as a matter of necessity: "O sodeyn wo, that evere art successour / To worldly blisse, spreynd with bitternesse, / The ende of the joye of oure worldly labour!" (lines $421-23){ }^{69}$

Unlike the narrator, who is concerned with happiness in this life and who worships Good Fortune in the person of Christ "that is to every harm triacle" (line 479), Custance worships Christ as the "Flemere of feendes" (line 46o). Her long prayer to the cross of Christ immediately follows the Man of Law's ejaculation to the "lord of Fortune" (line 448). She does not ask to be spared hardship and suffering; indeed, she clearly expects to "drenchen in the depe" (line 455). Her only concern is for her eternal salvation (line 454) and for the grace her "lyf t'amenden" (line 462). The sea reminds Custance not of the vagaries of fortune but of the "Lambes blood ful of pitee, / That wessh the world fro the olde iniquitee" (lines 452-53). She

69. As Robert Enzer Lewis has shown in "Chaucer's Artistic Use of Pope Innocent III's De Miseria Humanae Condicionis in the Man of Law's Prologue and Tale," $P M L A$ 81 (1966): 485-92, the narrator quotes the papal text here and elsewhere very selectively, while alerting the reader to larger spiritual contexts that counterbalance and correct his point of view. 
hopes that her own death by drowning will be a share in his victorious passion.

The narrator's commentary on Custance's time at sea consists of a series of rhetorical questions comparing her situation with that of Daniel, Jonas, Saint Mary of Egypt, and the five thousand fed in the desert, all of whom were helped by God. Not only are his citations less than accurate, but also they reflect a narrowly defined understanding of "purveiance" (line 483) as a provision for temporal welfare. Surely Chaucer uses the narrator's inept description of the working of God's providence and his appeal to authority- "as knowen clerkis" (line 48o) - to remind his readers of Boethius' Consolation, where opinions like the lawyer's are specified and judged to be false (Boece 1, pr.4.283-88): "the jugement of moche folk ne loken nothyng to the desertes of thynges, but oonly to the aventure of fortune; and jugen that oonly swiche thinges ben purveied of God, whiche that temporel welefulnesse commendeth."

The Man of Law is incapable of understanding providence as God's plan for humankind's eternal salvation, a loving plan that stands behind all events, even the most painful ones. As Lady Philosophy tells Boethius, "Purvyaunce embraceth alle thinges to-hepe, althoghe that thei ben diverse and although thei ben infinit," while destiny, in dependence on providence, "departeth and ordeyneth alle thinges singulerly" (Boece 4, pr.6.67-71). The Man of Law consistently reduces the providential to the fortunate.

Custance, on the other hand, recognizes that God's providential plan often includes temporal suffering and injustice. Banished from Northumbria by Alla's (forged) decree, Custance calls her husband "routheless" (line 863) and "harde" (line 857); she speaks of the innocence of her babe, "that nevere wroghtest synne" (line 856) and yet must suffer. But Custance goes beyond this recognition. She recalls that humankind's salvation came about through the crucifixion and death of Christ, the innocent Sufferer, and that "Mooder Marie" (line 841), the purest of women, witnessed her son's torments, seeing her "child ... on a croys yrent" (line 844) in atonement for the sins of others. Custance enters into her own passion "with an hooly entente" (line 867 ), embracing "the wyl of Christ" (line 825) and welcoming his "sonde" (line 826 ). She is prepared to die but also full of hope. She trusts not in the fateful stars but in the intercession of Mary, the "brighte sterre of day" (line 852), and in the power of 
God: "In hym triste I, and in his mooder deere, / That is to me my seyl and eek my steere" (lines 832-33). When Custance walks firmly down to the ship, carrying her child in her arms, she becomes an image of the inwardly free person described by Lady Philosophy (Boece $1, \mathrm{~m} .4 .1-7$ ): "Whoso it be that is cleer of vertue, sad, and wel ordynat of lyvynge, that hath put under fote the proude wierdes, and loketh upryght upon either fortune, he may holden his chere undesconfited. The rage ne the manaces of the see ... ne schal nat moeve that man." 70

If the memorable scene depicting Custance on the shore represents a certain climax in her development as a character and as a symbol-for in her moral mastery of destiny she becomes what she is literally called to be: Constance-there is no comparable development in the narrator. The rhetorical questions he interjects at lines 932-45 conform to the pattern of the earlier ones based on biblical exempla. He continues to reduce God's saving activity to temporal assistance, without seeing such interventions on the lower level as a shadowing forth of the work of salvation in souls. The narrator's final paraphrase of De contemptu mundi (lines 1 132-38), like the earlier ones, comments on the transitoriness of the "joye of this world" (line 1 133) without reference to the lasting joy that is a fruit of the Holy Spirit, and with scarcely an intimation of the "joye after wo" (line 1161 ) that the saints enjoy in heaven: "I ne seye but for this ende this sentence, / That litel while in joye or in plesance / Lasteth the blisse of Alla with Custance" (lines 1 139-41). In denial of the Man of Law's fatalistic assertion that earthly happiness "fro day to nyght ... changeth as the tyde" (line 1134), Custance's last years in Rome, spent "in vertu and in hooly almus-dede" (line 1156 ), in the midst of friends and family, seem like a pretasting of eternal happiness.

\section{Disparate Voices}

The primary verbal tension in "The Man of Law's Tale," then, is not (as in many saints' lives) between the heroine's voice and the voices of her pagan or diabolic persecutors but rather between the

7o. V. A. Kolve has beautifully documented the medieval use of the turbulent sea as an icon for the troubles and uncertainties of the human condition. See Chaucer and the Imagery of Narrative (Stanford, Calif.: Stanford University Press, 1984), pp. 32540. 
voices of Custance and the narrator with their subtly conflictive styles, genres, and points of view. A brief comparison of the trial scenes in "The Second Nun's Tale" and "The Man of Law's Tale" will illustrate the point. In Cecilia's trial before Almachius, she challenges him, speech by speech. When he asks about her "religioun and .. . bileeve" ( $S N T 4_{2}$ 7), she corrects him for asking "lewedly" (line 430) for two answers in a single question. When he complains about her rudeness and accuses her of lawbreaking, she points to her “ "innocence" " (line 452), " good feith'" (line 434), and obedience to “"conscience.'” His display of power prompts her reply: “'Youre myght . . f ful litel is to dreede'" (line 437). When Cecilia laughs aloud at his demand that she deny Christ, Almachius accuses her of pride. Once again she insists on another interpretation: "I speke noght but stedfastly,' quod she; / 'Nat proudly' (lines 474-75). She speaks " 'for my syde", (line 475) against her accuser, acting as her own advocate. Her providential view of things opposes Almachius' so that crime becomes innocence; vice, virtue; power, weakness; pride, fortitude; learning, lewedness; sight, blindness; death, life.

A similar double perspective on things emerges in Custance's trial, but there the dialogue between Christian defendant and pagan accuser is transformed into a more subtle opposition between $\mathrm{Cu}$ stance and her narrator-advocate. When the Man of Law interprets the trial scene as the pathetic tragedy of an unfortunate gentlewoman-apostrophizing "queenes, lyvynge in prosperitee" (MLT $65^{2}$ ) on behalf of Custance-he assumes a worldly point of view strangely akin to the idolatrous position taken by Cecilia's persecutor. The God who is present to Custance even in trial, even in death, is absent to him. He sees before him only an "Emperoures doghter" (line 655) standing alone and helpless, not the "doghter of hooly chirche" (line 675) vindicated by the Voice. Unlike Cecilia, Custance does not declare her innocence publicly before her judge; she prays instead privately to God: “ 'If I be giltless of this felonye, / My socour be" " (lines 643-44). Her prayer belies the narrator's claim: "She hath no wight to whom to make hir mone" (line 656). Indeed, in the very scene where he defends her innocence with pathetic appeals underscoring the absence of help- "no champioun" (line 631), "no grace" (line 647), no "freendes at . . grete nede" (line 658)Custance's recourse to a God present to her in prayer quietly prepares the way for miracles and conversion. 
By putting Custance's story on the lips of a sentimental (albeit sympathetic) narrator, Chaucer makes a powerful comment on the popular piety of his time that, with its misdirected veneration of the saints, threatened to obscure the true, exemplary power of their holy lives through "golden legends" and sensational display. ${ }^{71}$ The $\mathrm{Wy}$ cliffite treatises are full of complaints that popular preachers are making "longe talis of fablis, or cronyclis," instead of preaching "schortly" and "plenerly be gospel," 72 and misrepresenting the saints to justify their own worldly life styles: “. . f for pei louen welle to telle hou pis seynt or pis lyuede in gay and costly clopis \& worldly aray, \& 3it is a grete seynt." 73 In appealing for donations, moreover, they are using fabulous miracle stories to exploit people's desire for temporal well-being-even though, as the reformer insists, "bileue of hooly writ passip alle pes clepid myraclis." 74

The epilogue to the tale, which appears in 35 of the 57 manuscripts, suggests the kind of associational ambivalence surrounding exotic legends like that of Custance when Harry Bailey calls upon the Parson to follow the Man of Law's " "thrifty tale" " (MLT 1 165) with a reformist, Lollard “"predicacioun"” (line 1176 ). Chaucer's satire, with its disparate voices, makes its own call for reform without preaching simply by permitting Custance to speak, despite the windiness of her self-appointed spokesman. And that quiet voice, articulating a practical belief in divine providence, manages to be heard.

The lives of the three saints-Eustace, Griselda, and Custancewhich we have examined all conform to the pattern of Job's life. As a scriptural hero, Job mediates typologically between the old heroes of pagan romance and the new heroes of Christian hagiography. The truth of Job's story thus verifies the extravagance of legend as in each case the exemplary virtue of the hero or heroine is tested, proved, and rewarded. The extraordinary trials which constitute the exterior action of the tales are matched by the equally remarkable

71. Sherry L. Reames charts the reaction against this sort of piety in The Legenda Aurea: A Reexamination of Its Paradoxical History (Madison: University of Wisconsin Press, 1985). See also William C. Johnson, Jr., “'The Man of Law's Tale': Aesthetics and Christianity in Chaucer," Chaucer Review 16.3 (1982): $201-21$.

72. "The Rule and Testament of St. Francis," in John Wyclif, The English Works of Wyclif, ed. F. D. Matthew, EETS, vol. 74 (London: Trübner, 1880 ), p. 50.

73. "The Office of Curates," in ibid., p. 153.

74. "De Papa," in ibid., p. 469. 
long-suffering of the protagonists, whose patient endurance and selfcontrol constitute the heroic inner action, the static center, of the legends.

Whereas the relatively straightforward didacticism of the Eustace legend encourages the acceptance of passive purification and the exemplum of Petrarch's Griselda similarly teaches patience in adversity, the Chaucerian romances of Griselda and Constance complicate the plots of serial suffering, fortitude, and final reward through biblical concordance and Boethian allusion. As a result the fundamental synthesis of hagiography and romance becomes a fertile meeting ground for philosophy and theology. The Old Testament story of Job no longer mediates simply between parallel secular and sacred stories. Instead the saintly lives of Griselda and Constance mediate between Job and Boethius. Superimposed allusively on Chaucer's legenda, the pathetic outcry of Job merges with the apostrophic weeping of the Boethian prisoner, the suffering of Job with the suffering of Christ, the silence of Job with the wisdom of Lady Philosophy, demonic attack with the blows of misfortune and injustice, happy endings with divine intervention and providential design. 